\title{
GENOTYPIC IDENTIFICATION OF CANDIDA SPP. ISOLATED FROM ONYCHOCANDIDIASIS PATIENTS BY PHENOTYPIC METHODS, PCR AND RAPD-PCR
}

\author{
${ }^{1}$ Zaidan Khlaif Imran and ${ }^{2} \mathrm{H}$. Al-Ghalibi \\ ${ }^{1}$ All Women College of Science, Babylon University, Hilla, Iraq \\ ${ }^{2}$ Al-Qadisiya University, AL-Dewania, Iraq
}

Received 2013-12-19; Revised 2013-12-31; Accepted 2013-12-31

\begin{abstract}
Candidal Onychomycosis (COM) is a common nail disease which plays as sources pathogenic reservoir giving a rise to repeated candidiasis infections. This study aimed to evaluate PCR assays and phenotypic tests for identification of yeasts isolated from COM patients. The study included 100 clinically suspected patients of COM attending the main hospital and clinics in Al-Dewania province in the middle of Iraq during September 2011 to April 2012. One hundred yeast isolates were identified morphologically by CHROMagar medium. DNA was extracted from 14 representative's isolates for accurate identification by PCR and fingerprinted by RAPD-PCR. Phenotypic examination of 100 yeasts isolates on CHROMagar revealed that these isolates were classified into 7 different species belonged to Candida form genus, PCR assay revealed that primer pair ITS1 and ITS4 was successfully amplified ITS1-5.8S-ITS2 rDNA region for 14 isolates of Candida spp. yielding a unique PCR products approximately 510-650bp in length. The results of RAPD-PCR assay showed that both primers (TAGGATCAGA and AGGTCACTGA) were genotyped 14 isolates of Candida into seven main genotypes; three of these genotypes had highly percentage of homologous (80-100\%) among related isolates were studied in each Candida isolates, while the others four genotypes had 10-50\% homologous. This study concluded that for accurate and prices identification must used PCR and fingerprinted by RAPD-PCR assays, the results of CHROMagar were correlated with gene expression for each Candida isolates, while the results of RAPD PCR assay were correlated with degrees similarity and difference of genotypes for Candida isolates under interest.
\end{abstract}

Keywords: Onychomycosis, Candida spp., Genotyping, PCR, RAPD-PCR, CHROMagar, Iraq

\section{INTRODUCTION}

Candidal Onycho Mycosis (COM) represents one of the nail diseases caused by Dermatophytes and nondermatophyte mold and yeasts. COM representative bout $30 \%-50 \%$ of all nail diseases which caused by fungi (Midgley et al., 1994; Garg et al., 2004). Candida spp. Are composing a part of the normal flora that inhabits the human body included: Vagina, mouth, anal, skin and gastrointestinal tract. These fungi can invade skin and nail in immunocopennt and immunocompromised patients, diabetes, transplanted organs, highly antibiotic uses. Candida spp. was attacked individuals those exposed for nail damage or injury, hot and humid climates (Heikkila and Stubb, 1995; Rigopoulos et al., 1998). One of the risk factors that lead to nail yeast infection is frequent and prolonged exposure to water, mostly infected different age and sex groups of human those followed bad hygiene, share communal showers, farmers and hard workers (Davenport and Wilton, 1971; Jesudanam et al., 2002; Wang and Ching, 2005; Ching et al., 2005).

Previous studies refer that patients between 21 and 40 years old were had potential Onychomycosis (Vinod et al., 2000; Grover, 2003; Vijaya et al., 2004; Agarwalla et al., 2006). C. albicans and non-albicans species causes virulence such as $C$. glabrata have appeared as important Corresponding Author: Zaidan Khlaif Imran, All Women College of Science, Babylon University, Hilla, Iraq Tel: 00960780329448 
pathogens (Odds et al., 1990; Canteros et al., 1994; Bokhari et al., 1999; Agarwalla et al., 2006).

Identified pathogenic yeasts based on biochemical tests and phenotypic characters Such as colonial colors on CHROMagar, show reliable methods for identification but not clear cut identification furthermore most of conventional approaches were time consuming (48 to $72 \mathrm{~h}$ ) to perform identification task delayed performed, subjected to limitations, challenges because some of biochemical tests sometime fail to identify causing agents, many reports show that $12 \%$ of tested isolates need additional treatment and $0.8 \%$ are not well identified (Beighton et al., 1995; Tarini et al., 2010).

Recent studies reported that the identification the Candida spp. by utilized molecular methods such as PCR and RAPD assays fulfill rapid identification of yeasts with high level of sensitivity and specificity (Chang et al., 2001; Khlif et al., 2007) and have been more reliable and accurate yielded results and fulfilled in a short time about 3-5 h, compared with conventional approaches and aid in faster diagnosis and prescribe drugs for patients improved chance of treatment and survival (McCullough et al., 1994; Xiang et al., 2007). This study was aimed to evaluate using of PCR assays beside phenotypic tests for identification of yeasts isolated from Onychomycosis patients in Iraq.

\subsection{Patients}

One hundred samples of nails had been collected from clinically suspected patients with Onychomycosis who attending private clinics in most regions of Al-Dewania province, Iraq and from outpatients attending Al- Dewania main hospital in the middle of Iraq. The period of sampling extended from between August 2011 to July 2012.

\section{MATERIALS AND METHODS}

1-Yeast isolates identification the samples were cultured on Potato Dextrose Agar (PDA) and incubated at $28^{\circ} \mathrm{C}$ for $2-14$ days. After $24-48 \mathrm{~h}$, yeast colonies isolated in pure cultures by streaking on PDA and on CHROMagar medium were subjected to preliminary identification assays (Pfaller et al., 1996).

A Tiny portion of each colony was mounted on slide with drop of lactophenole cotton blue stain and covered with slide cover and examined under high power for detection of the presence of chlamydospores. Fourteen representatives isolate were subcultured on Sabouraoud's dextrose agar for DNA Extraction.

\subsection{DNA Extraction}

For extracting genomic DNA of Candida isolates, a single colony for each isolate was taken by sterile loop and pick up in $600 \mu \mathrm{L}$ of lysis buffer $(200 \mathrm{mM}$ Tris-Hcl $\mathrm{pH} 8,40 \mathrm{mM}$ EDTA, 1.5\% SDS and $150 \mathrm{mM} \mathrm{NaCl}$ ) in a sterile tube. Few yellow sand was added to the cell suspension for disruption cell wall of yeast followed by heating for $85^{\circ} \mathrm{C}$ and vortex. $600 \mu \mathrm{L}$ of $25: 24: 1$ volume of a mixture of Phenol: Chlorophorm: Isoamyl alcohol was added to cell suspension, vortexed for $5 \mathrm{~min}$ and centrifuged $5000 \mathrm{rpm}$ for $3 \mathrm{~min}$. The supernatant was transferred to a clean tube and $400 \mu \mathrm{L}$ of chloroform was added. After centrifuging as the previous conditions, the aqueous phase was transferred to a clean tube and then $160 \mu \mathrm{L}$ of $3 \mathrm{M}$ sodium acetate ( $\mathrm{pH} 5.2$ ) were added and was kept on $-20^{\circ} \mathrm{C}$ for $10 \mathrm{~min}$, centrifuged for at 10000 rpm for $5 \mathrm{~min}$. The supernatant was transferred to a clean tube added and two volumes of isoprobanol were mixed gently and centrifuged $12000 \mathrm{rpm}$ for $12 \mathrm{~min}$. The supernatant discharged, the DNA pellet washed twice with $70 \%$ ethanol, dried and re-suspended within $50 \mu \mathrm{L}$ distilled water and the sample was kept at $-20^{\circ} \mathrm{C}$ until use (Mannarelli and Kurtzman, 1998).

\subsection{PCR Conditions}

The ITS1-5.8S-ITS2 rDNA regions was targeted PCR amplification using primer pairs ITS1 (forward, 5-TCC GTA GGT GAA CCT GCG G-3 and ITS4 (reverse, 5TCC TCC GCT TAT TGA TAT GC-3). PCR amplification was performed in a final volume of $30 \mu \mathrm{L}$. Each reaction consists of $0.7 \mu \mathrm{L}$ template DNA, $0.5 \mu \mathrm{l}$ of each primer at 20 pemole, $5 \mu \mathrm{L}$ master mix (Bionner Company, Korea). The amplification conditions were as follows: Initial denaturation cycle at $94^{\circ} \mathrm{C}$ for $5 \mathrm{~min}$, followed by 35 cycles denaturation at $94^{\circ} \mathrm{C}$ for $1 \mathrm{~min}$, annealing at $56^{\circ} \mathrm{C}$ for $1 \mathrm{~min}$, extension at $72^{\circ} \mathrm{C}$ for $1 \mathrm{~min}$ and in the final cycle the final extension step was $72^{\circ} \mathrm{C}$ for $7 \mathrm{~min}$. Eight $\mu \mathrm{L}$ of PCR products were visualized by $1 \%$ agarose gel electrophoresis in TAE buffer $(\mathrm{pH} 8)$. The gel was stained with $0.05 \%$ ethidium bromide premixed with agarose. The DNA bands were detected by Desk Gel imager scope 21 ultraviolet transilluminator.

\subsection{RAPD-PCR}

RAPD-PCR was accomplished with total volume 50 $\mu \mathrm{L}$ consist of $10 \mu \mathrm{L}$ of $10 \mathrm{x}$ master mix (Bionner, Korea) with $37 \mu \mathrm{L}$ DDW and $1.5 \mu \mathrm{L}$ (50 pmole) for each random primers TAGGATCAGA and AGGTCACTGA (Valerio et al., 2006). The mixture was amplified using the following conditions: $95^{\circ} \mathrm{C}-4 \mathrm{~min}, 38$ cycles $94^{\circ} \mathrm{C} 1$ $\min -36^{\circ} \mathrm{C} 1.5 \min 72^{\circ} \mathrm{C} 1.30-72^{\circ} \mathrm{C} 8 \mathrm{~min}$ (LABNET PCR System). The $8 \mu \mathrm{L}$ of PCR products were run on 
$1.5 \%$ agarose gel at 55 volts for $1 \mathrm{~h}$. The gel was stained with $0.05 \%$ ethidium bromide premixed with agarose. The DNA bands were detected by Desk Gel imager scope 21ultraviolet transilluminator.

RAPD-PCR products were subjected to Phylogenetic analysis and the phylogenetic tree denedrograms (UPGMA) were constructed by using UVI band software and evaluated the similarity coefficient factor according to (Mackenstedt et al., 1994).

\section{RESULTS}

\subsection{Isolation and Identification of Candida spp}

Phenotypic examination of 100 yeasts isolates on CHROMagar revealed that these isolates were classified into 7 species belonged to Candida form genus. The percentages of the identified species were: Candida albicans $29 \%$, C. tropicalis 25\%, C. krusei 28\%, C. guilliermondi $10 \%$, C.famata $3 \%$, C. parapsilosis $1 \%$, while $4 \%$ of isolates were recognized as C.kefyr based on colors on CHROMagar medium (Table 1).

\subsection{Germ tube and Chlamydospore Formation}

Results showed that the chlamydospore was produced abundantly single, in Clusters, or contiguous pairs in $C$. albicans produced. Two species produce germ tube, the green and pale green to dark blue color of colonies on CHROMagar refer to C. albicans, C. tropicals, while C.krusei, C. guilliermondi and C.kefyr they show Pink to white, Green to Pink and Cream to pink color respectively (Table $\mathbf{1})$.

\subsection{Simple PCR}

The primer pair ITS1 and ITS4 was successfully amplified ITS1-5.8S-ITS2 rDNA region for 14 clinical
Candida spp. isolates, yielded range of PCR products between 510-650 bp they are: Lanes $(\mathrm{B}-\mathrm{C})=$ C.albicans $(529-535 \mathrm{bp})$, lane $(\mathrm{E})=C$, prapsilosis $(511-520 \mathrm{bp})$. Lanes $(\mathrm{I}, \mathrm{F}, \mathrm{K})=C$. krusei $(500-510 \mathrm{bp})$. Lane $(\mathrm{O})=$ C.guilliermondi (590-610 bp). Lanes (H, D, J, G, L) $=C$. tropicals $(517-525 \mathrm{bp})$. Lane $(\mathrm{M})=$ C. famata $(630-640$ $\mathrm{bp})$. Lane $(\mathrm{N})=C$. kefyr $(650 \mathrm{bp})$ (Fig. 1).

\subsection{RAPD -PCR}

The results showed that both primers (AGGTCACTGA and TAGGATCAGA) were successfully genotyped 14 isolates RAPD-PCR produced multiple bands with primer (AGGTCACTGA), the main band was consistently present in all isolates (Constant basal band 450-550 bp), but greatest variation occurred among the upper bands of constant single bands at 600800 bp while the lowest were at 200-400 bp (Fig. 2). While the primer (TAGGATCAGA) was successfully fingerprints were identified by two constant double bonds in the size range between at 1000-1500 bp. Lower bands at 150-250 bp, 150-300 bp and 350-500 bp with extra band $200 \mathrm{bp}$ for some isolates (Fig. 4).

Table 1. Summarized main characteristics of Candida spp. isolates from infected nails of patients

\begin{tabular}{llll}
\hline Candida spp. & $\begin{array}{l}\text { Percentage } \\
(\%)\end{array}$ & $\begin{array}{l}\text { Germ tube } \\
\text { Formation }\end{array}$ & $\begin{array}{l}\text { Color on } \\
\text { CHROMagar }\end{array}$ \\
\hline C. albicans & 29 & + & Green \\
C. tropicals & 25 & - & Dark blue \\
C. krusei & 28 & + & Pink to white \\
C. famata & 3 & - & blue-pink \\
C. prapsilosis & 1 & - & Pink to White \\
C. kefyr & 4 & - & Cream to pink \\
C.guilliermondi & 10 & - & Green to Pink \\
\hline
\end{tabular}

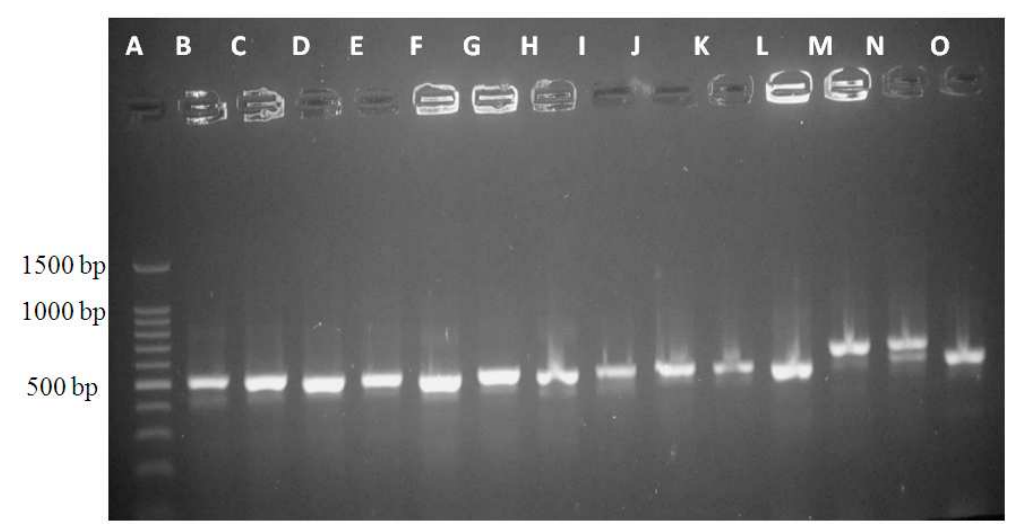

Fig. 1. Agarose gel electrophoresis of amplified PCR product for ITS1-5.8s-ITS2 rDNA of Candida spp. Primer pair ITS1/ITS4. Lane A = Molecular marker 100 bp; lanes B-O, clinical of Candida isolates 


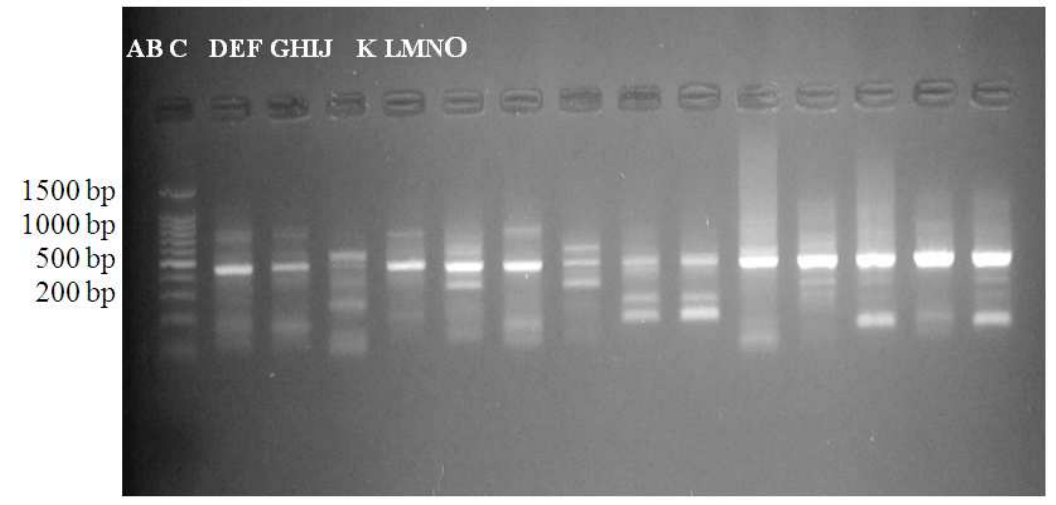

Fig. 2. Agarose gel electrophoresis of amplified RAPD-PCR products for Candida spp. Detection polymorphism of 14 clinical isolates of Candida isolates. Using primer AGGTCACTGA. Lane A = Molecular marker 100 bp; lanes B-O, clinical isolates of Candida spp.

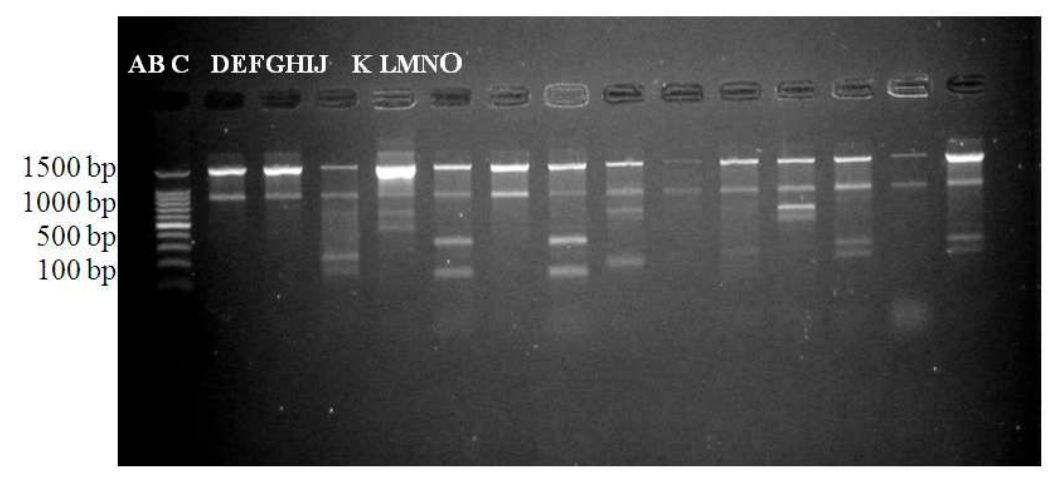

Fig. 3. Agarose gel electrophoresis of amplified RAPD-PCR products for Candida isolates. Detection polymorphism of 14 clinical isolates of Candida spp. Using primer TAGGATCAGA. Lane A= Molecular marker 100 bp; lanes B-O, clinical isolates of Candida spp.

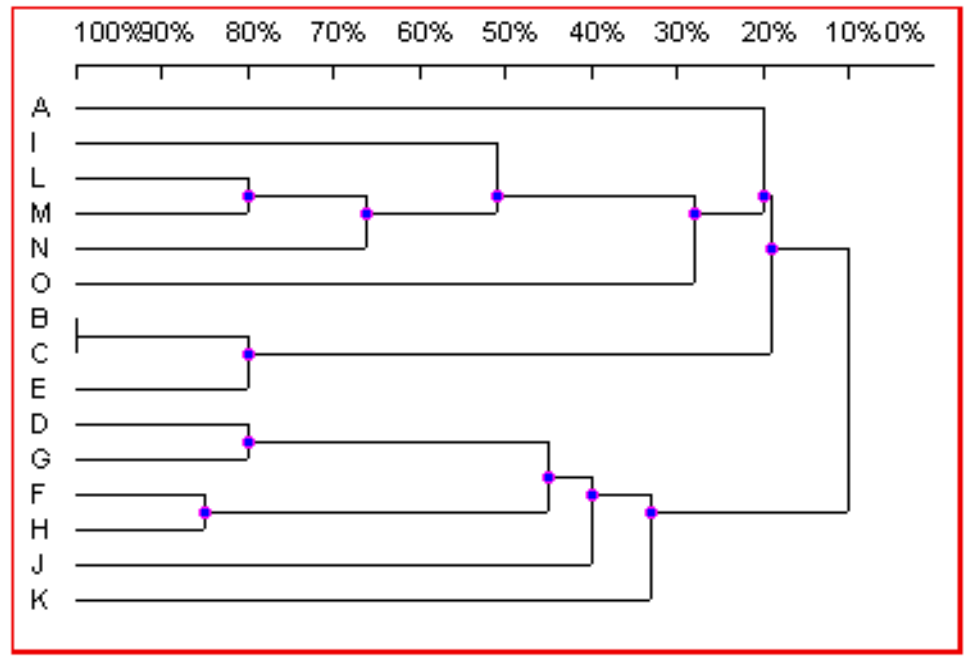

Fig. 4. Phylogenetic tree dendrogram (homologous coefficient \%) between different isolates of Candida. Based on the RAPD-PCR by AGGTCACTGA primer. Was generated via UPGMA cluster analysis, lane A = Molecular marker, lanes I-K, clinical Candida isolates 


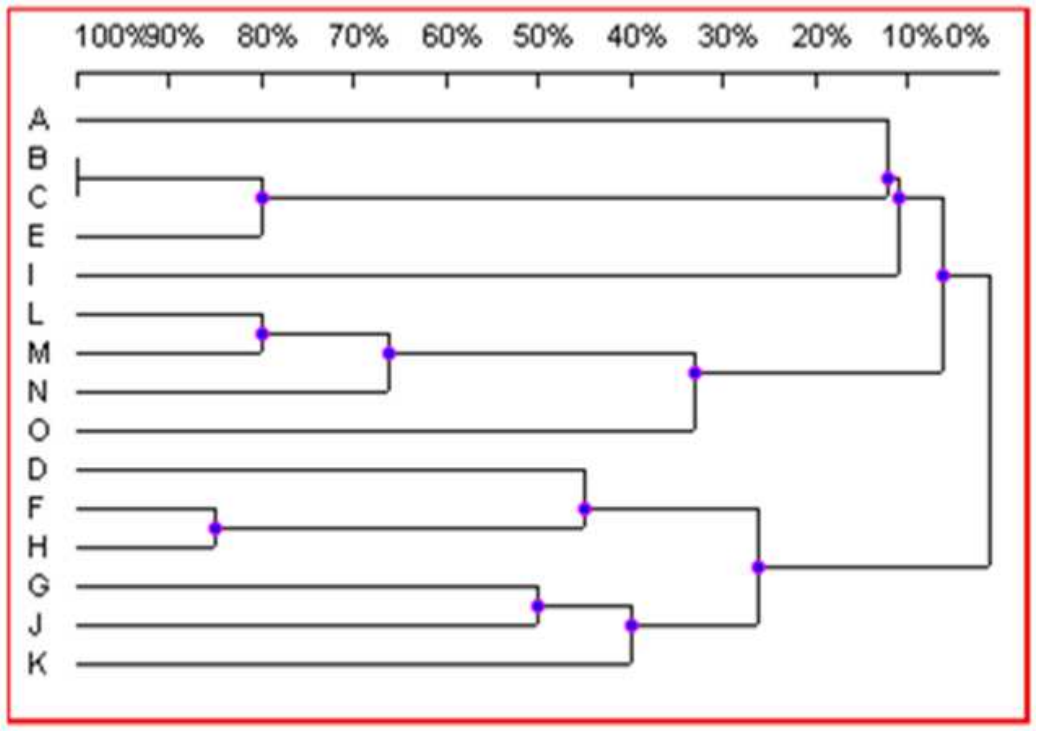

Fig. 5. Phylogenetic tree dendrogram of Candida isolates. Based on the RAPD-PCR by TAGGATCAGA primer. Was generated via UPGMA cluster, analysis, lane A = Molecular marker and lanes B-K, clinical Candida isolates

Phylogeny of RAPD-PCR produced created 3 main genotypes have homologous percentage with high of ranged between $80-100 \% \quad(B \& C, \quad L \& M$ and $\mathrm{F} \& \mathrm{H}$ genotype), while create 5 genotypes have homologous $10-50 \%$ (O, I, N, J and K genotype) (Fig. 3 and 5).

\section{DISCUSSION}

Candidal Onychomycosis is the most common diseases that widely prevalent in most sex and age's groups of patients that required for rapid presumptive identification by reliable and precise methods (Chang et al., 2001). CHROMagar was developed for presumptive identification of important Candida spp (Beighton et al., 1995). The identification of Candida species based on colony color on CHROMagar was showed some confusion between closely related species like $C$. albicans and $C$. tropicalis, no border line separated them because these isolates produced a wide spectrum in color from light blue-green, pale green to dark green color under the same incubation conditions, also C.kefyr, C. guilliermondi and $C$. krusei revealed pink-white color,. The CHROMagar medium was stilled an important test for pre-identifying many Candida species.

Molecular assay by Amplified ITS1-5.8S-ITS2 region was showed high distinctive species of Candida. The PCR products for 14 isolates of Candida which isolated from patient's nails were yielded genotypes had PCR products approximately ranged from 500-650 bp (included primer) and supported classified 7 species of
Candida, C. albicans, C. tropicalis, C. krusei, C. parapsilosis, C. famata, C. kefyr and C. guilliermondi (Fig. 2) are rapid and sensitive alternatives for the identification of these species. Beighton et al. (1995) and Fujita et al. (2001) the amplified products by being coincident with the many previous studies (Tarini et al., 2010; Mousavi et al., 2012).

RAPD-PCR by two oligo-primers (AGGTCACTGA) and (TAGGATCAGA) showed special fingerprinting patterns for all Candida isolates. Phylogenetic tree denedrograms of Candida isolates showed variable degrees of homogeneous percentage from $100 \%$ in closed related isolates as in B\&C (Fig. 3 and 5). Both primer gave similar patterns of RAPD PCR products in some isolates which appeared had the same fingerprinting genotypes. Our results were coincidence with the results of Tamura et al. (2001). The oligoprimers sometimes have great potential for detecting polymorphisms of many isolates within one species and in different species and removed the skeptical issue about discrimination potential of oligoprimers but the results of this study showed opposite to the idea that say oligoprimers may produced poorer at discriminating between the strains of another species (Roberts, 1992; Sullivan et al., 1995; Vinod et al., 2000).

\section{CONCLUSION}

This study concluded that identification of Candida spp. by phenotypic assays such CHROMagar and 
culture characters were appeared less reliable comparing with results were conducted by genotyping by and PCR and RAPD-PCR assays, which facilitate identification of Candida spp. in clinical laboratories. The results of PCR and procedures described here allowed the identification of $C$. albicans and nonalbicans. Also the genotyping of Candida isolates by RAPD-PCR revealed highly discriminated for genotypes of Candida and showed the precise similarity degrees of the isolates genotypes. Comparing with the results of CHROMagar which showed confusions in colors of some isolates of Candida.

\section{ACKNOWLEDGMENTS}

The molecular part of this study was performed by the first author in Biotechnology Lab. Biology department, all women college of Science, Babylon University, while the phenotypic part was performed by the second author in Al-Qadisiya University, unfortunately but he was dead before he finished this research. May God bless him with paradise heaven. I would like to thank Al-Qadisiya University and AlQadisiya hospital staff for their logistic support and their help in sampling and thank all women college of Science, Babylon University. The author also thank Dr. Mohamed Al-Rufaie for his help.

\section{REFERENCES}

Agarwalla, A., S. Agrawal and B. Khanal, 2006. Onychomycosis in Eastern Nepal. Nepal Med. Coll. J., 8: 215-219. PMID: 17357634

Beighton, D.R., D. Ludford, T. Clark, S. Brailsford and C. Pankhurst et al., 1995. Use of CHROMagar Candida medium for isolation of yeasts from dentalsamples. J. Clin. Microbiol., 33: 3025-3027. PMID: 8576366

Bokhari, A., I. Hussain, M. Jahangir, S. Haroon and S. Aman et al., 1999. Onychomycosis in Lahore, Bakistan. Int. J. Dermatol., 38: 591-595. DOI: 10.1046/j.1365-4362.1999.00768.x

Canteros, E., O. Davel and W. Vivot, 1994. Causal agents of Onychomycosis. Rev. Argent Microbiol., 26: 65-71. PMID: 7938504

Chang, C., N. Leaw, H. Huang, L. Wu and C. Chang, 2001. Rapid identification of yeasts in positive blood cultures by multiplex PCR method. J. Clin. Microbiol., 39: 3466-3471. DOI: 10.1128/JCM.39.10.3466-3471.2001
Ching, C., H. Wang and C. Chou, 2005. The causative pathogens of Onychomycosis in Southern Taiwan. Mycoses, 48: 413-420. DOI: 10.1111/j.14390507.2005.01152.x

Davenport, C. and A. Wilton, 1971. Incidence of immediate and delayed hypersensitivityto Candida albicans indenture stomatitis. J. Dent. Res., 50: 892-896. DOI: 10.1177/00220345710500041701

Fujita, S., Y. Senda, S. Nakaguchi and H. Hashimoto, 2001. Multiplex PCR using internal transcribed spacer and 2 regions for Rapd detection and identification of yeast strains. J. Clin. Microbial., 39: 3617-3622. DOI: $10.1128 / J C M .39 .10 .3617-$ 3622.2001

Garg, A., V. Venkatesh, M. Singh, P. Pathak and P. Kaushal et al., 2004. Onychomycosis in central India: A clinicoetiologic correlation. Int. J. Dermatol., 43: 498-502. DOI: 10.1111/j.13654632.2004.02125.x

Grover, S., 2003. Clinico-mycological evaluation of onychomycosis at Bangalore and Jorhat. Indian J. Dermatol. Venereol. Leprol., 69: 284-286. PMID: 17642913

Heikkila, H. and S. Stubb, 1995. The prevalence of onychomycosis in Finland. Brit. J. Dermatol., 133: 699-703. DOI: $10.1111 / \mathrm{j} .1365-$ 2133.1995.tb02741.x

Jesudanam, M., R. Rao, J. Lakshmi and R. Kumari, 2002. Onychomycosis: A significantmedical problem. Indian J. Dermatol. Venereol. Leprol., 68: 326-329. PMID: 17656990

Khlif, M., H. Sellami, A. Sellami, F. Makni and F. Cheikhrouhou et al., 2007. Detection and identification of Candida sp.by PCR in Candidemia Diagnosis. J. Mycol. Med., 17: 256-260. DOI: 10.1016/j.mycmed.2007.10.001

Mackenstedt, U., K. Luton, P.R. Baverstock, A.M. Johnson, 1994. Phylogenetic relationships of Babesia divergens as determined from comparison of small subunit ribosomal RNA gene sequences. Mol. Biochem. Paras., 68: 161-165. PMID: 7891742

Mannarelli, M. and P. Kurtzman, 1998. Rapid identification of Candida albicans and other human pathogenic yeasts by using short oligonucleoides in a PCR. J. Clin. Microbiol., 36: 1634-1641. PMID: 9620392 
McCullough, J., C. Ross, D. Dwyer and C. Reade, 1994. Genotype and phenotype of oral Candida albicans from patients infected with the human immunodeficiency virus. Microbiology, 140: 11951202. DOI: 10.1099/13500872-140-5-1195

Midgley, G., K. Moore, C. Cook and G. Phan, 1994. Mycology of nail disorders. J. Am. Acad. Dermatol., 31: 68-74. DOI: 10.1016/S0190-9622(08)81272-8

Mousavi, A., S. Salari, S. Rezaie, S. Nejad and S. Hadizadeh et al., 2012. Identification of Candida species isolated from oral colonization in iranian HIV-positive patients, by PCR-RFLP method. Jundishapur J. Microbiol., 5: 336-340. DOI: 10.5812/kowsar.20083645.2429

Odds, F.C., J. Schmid and D.R. Soll, 1990. Epidemiology of Candida Infections in AIDS. In: Mycoses in AIDS Patients, Bossche, H.V.D. (Ed.), Springer Verlag Gmbh, New York, ISBN-10: 030643704X, pp: 67-74.

Pfaller, A., A. Houston and S. Coffmann, 1996. Application of CHROMagar Candida for rapid screening of clinical specimens for Candida albicans, Candida tropicalis, Candida krusei and Candida (Torulopsis) glabrata. J. Clin. Microbiol., 34: 58-61. PMID: 8748273

Rigopoulos, D., V. Katsiboulas, E. Koumantaki P. Emmanouil and A. Papanicolaou et al., 1998. Epidemiology of onychomycosis in Southern Greece. Int. J. Dermatol., 37: 925-928. DOI: 10.1046/j.1365-4362.1998.00613.x

Roberts, T., 1992. Prevalence of dermatophyte onychomycosis in the united kingdom. Br. J. Dermatol., 126: 23-27. DOI: 10.1111/j.13652133.1992.tb00005.x

Sullivan, J., J. Westerneng, A. Haynes, E. Bennett and C. Coleman, 1995. Candida dubliniensis sp. nov.: phenotypic and molecular characterization of a novel species associated with oral candidosis in HIV-infected individuals. Microbiology, 141: 15071521. DOI: $10.1099 / 13500872-141-7-1507$
Tamura, M., K. Watanabe, Y. Mikami, K. Yazawa and K. Nishimura, 2001. Molecular characterization of new clinical isolates of candida albicans and c.dubliniensis in Japan. Int. J. Clin. Microbiol., 39: 4309-4315. DOI: 10.1128/JCM.39.12.43094315.2001

Tarini, N.M.A, I. Mardiastuti, H. Wahid, F. Ibrahim and A.Yasmon et al., 2010. Development of multiplex-PCR assay for rapid detection of Candida spp. Med. J. Indones., 19: 83-88. DOI: 10.13181/mji.v19i2.387

Valerio, M., B. Weikert-Oliveira1 and A. deResende, 2006. Differentiation of Candida species obtained from nosocomial candidemia using RAPD-PCR technique. Rev. Soc. Bras. Med. Tropical., 39: 174178. DOI: $10.1590 /$ S0037-86822006000200008

Vijaya, D., H. Anandkumar and H. Geetha, 2004. Study of onychomycosis. Indian J. Dermatol. Venereol. Leprol., 70: 185-186. PMID: 17642607

Vinod, S., S. Grover, K. Dash and G. Singh, 2000. A clinico-mycological evaluation of onychomycosis. Ind. J. Dermatol. Venereol. Leprol., 66: 238-230. PMID: 20877087

Wang, H. and C.C. Ching, 2005. Onychomycosis in Taiwan. Int. J. Clin. Prac., 59: 906-911. DOI: 10.1111/j.1742-1241.2005.00497.x

Xiang, H., L. Xiong, X. Liu and Z. Tu, 2007. Rapid simultaneous detection and identification of six species candida using polymerase chain reaction and reverse line hybridization assay. J. Microbiol. Methods, 69: 282-2887. DOI: 10.1016/j.mimet.2007.01.011 